\title{
Correction to: Determining the long-term habitat preferences of the Duke of Burgundy butterfly, Hamearis lucina, on a chalk grassland reserve in the UK
}

\author{
M. P. Hayes ${ }^{1}$ - G. E. Hitchcock ${ }^{2}$ - R. I. Knock ${ }^{2}$ - C. B. H. Lucas $^{2}$ · P. K. Chaney ${ }^{2}$ - M. W. Rhodes ${ }^{1}$ - E. C. Turner ${ }^{1}$
}

Published online: 15 November 2018

(c) The Author(s) 2018

\section{Correction to: \\ Journal of Insect Conservation (2018) 22:329-343 \\ https://doi.org/10.1007/s10841-018-0065-9}

In the original publication, the order of authors was incorrect. The correct order is given in this Correction.
Open Access This article is distributed under the terms of the Creative Commons Attribution 4.0 International License (http://creativeco mmons.org/licenses/by/4.0/), which permits unrestricted use, distribution, and reproduction in any medium, provided you give appropriate credit to the original author(s) and the source, provide a link to the Creative Commons license, and indicate if changes were made.

The original article can be found online at https://doi.org/10.1007/ s10841-018-0065-9.

\section{P. Hayes}

mph51@cam.ac.uk

1 Department of Zoology, University Museum of Zoology,

Downing Street, Cambridge CB2 3EJ, UK

2 Wildlife Trust for Bedfordshire, Cambridgeshire,

Northamptonshire and Peterborough, Priory Country Park,

Barkers Lane, Bedford MK41 9SH, UK 